ГЕРАСИН Дмитрий Леонидович - аспирант кафедры философии и социологии Академии труда и социальных отношений (119454, Россия, г. Москва, ул. Лобачевского, 90; cleverman121@gmail.com)

\title{
СОВЕРШЕНСТВОВАНИЕ ЭЛЕКТОРАЛЬНЫХ ПРАКТИК В ПЕРИОД ГЛОБАЛЬНЫХ КРИЗИСОВ
}

\begin{abstract}
Аннотация. В статье оцениваются риски для эффективного функционирования избирательной системы, которые могут возникнуть в периоды глобальных кризисов. Автор приходит к выводу, что следствием масштабных кризисных явлений (например, пандемия COVID-19) может явиться спад электоральной активности. В данных условиях особую востребованность приобретают современные информационно-коммуникационные инструменты и политические технологии, способные обеспечить мобилизацию избирателей. Соответственно, уже в ближайшей перспективе дистанционные формы политического участия имеют все шансы стать реальной альтернативой традиционных практик.

Ключевые слова: глобальный кризис, гражданское общество, выборы, избирательная система, мобилизация, электоральная активность
\end{abstract}

$\mathrm{B}$ сякий раз, когда речь заходит о влиянии глобализации на благополучие и стабильность национальных государств, констатируется угроза возникновения кризисов, способных единовременно нанести колоссальный ущерб всем странам, интегрированным в транснациональную финансово-экономическую систему. При этом за скобки выносится возможность возникновения непрогнозируемых угроз, которые способны в одночасье изменить привычный уклад экономической и политической жизни. Доказательством вышеприведенного утверждения служит пандемия COVID-19, к масштабам которой ни одна из стран мира не была готова в должной мере. Впрочем, именно эта неготовность к рациональному противодействию кризисам заставила многих политиков и экспертов разочароваться в универсальных либеральных подходах к государственному строительству и реализации властных отношений. Оказалось, что полагаться на институты глобального управления крайне опасно и бесперспективно (об этом в свое время предупреждали некоторые отечественные исследователи [Фельдман 2015]). Возникла необходимость выработки на национальном уровне инновационных механизмов и технологий, способных в кратчайшие сроки обеспечить экстренную мобилизацию ресурсов государства и общества. Так, резкое ухудшение эпидемиологической ситуации в мире стало вызовом для национальных избирательных систем, поскольку на фоне угрозы жизни и здоровью людей сохранилась необходимость формирования легитимных органов власти посредством электоральных процедур.

Любой глобальный кризис обладает высокой степенью инклюзивности, что обусловливает его комплексное негативное воздействие на все сферы общественной жизни. Пандемия COVID-19 стала ярким примером подобных дестабилизирующих факторов. Она значительно усложнила воплощение долгосрочных инициатив государства и бизнеса, поставив под угрозу полноценную реализацию национальных проектов 2018-2024 гг., которые были утверждены президентом РФ за 2 года до ее начала. Д.А. Ежов справедливо отмечает, что невозможность реализации национальных проектов в первоначальном их виде из-за пандемии COVID-19 требует от правительства сконцентрировать дополнительные усилия на достижении обозначенных целей, ведь процесс модернизации страны обладает критической важностью для ее будущего благополучия [Ежов 2020]. Другими словами, для продолжения модернизационного курса российское государство должно мобилизовать ограниченные из-за пандемии 
ресурсы, что еще раз подчеркивает необходимость совершенствования национальных политических институтов и практик.

Проведение выборов в условиях кризисов и масштабных потрясений всегда сопряжено с серьезными проблемами. Любое государство в подобных обстоятельствах сталкивается с невозможностью следования ранее избранной стратегии развития, что обусловливает необходимость выделения дополнительных ресурсов на антикризисные меры. При этом избирательная система оказывается в крайне уязвимом положении, ведь ее способность к самовоспроизводству политики зачастую переоценивают. На фоне глобальных кризисов и катастроф граждане нередко теряют интерес к выборам, поскольку стремление к политическому участию вытесняется в их сознании необходимостью обеспечить собственное физическое выживание. Электоральные процессы попросту выпадают из перечня общественных приоритетов. При этом даже крупные политические силы стараются отстраниться от борьбы за власть, чтобы снять с себя ответственность за выход из сложившейся кризисной ситуации. Как следствие, возникает гражданская апатия и абсентеизм, когда люди отказываются от участия в голосовании из-за того, что исход выборов, с их точки зрения, не имеет особого значения. Вероятно, именно этим фактором объясняется низкая явка граждан РФ в Единый день голосования 2020 г.

Для решения выявленной нами проблемы государству и иным субъектам политического процесса необходимо выработать инновационные методы стимулирования электоральной активности, которые бы эффективно применялись во время глобальных кризисов. Прежде всего, нужно сосредоточить усилия на повышении общественного интереса и доверия к институту выборов. Российский исследователь П.Я. Фельдман указывает на своеобразный парадокс в системе электорального представительства интересов. С одной стороны, государство призывает к активному участию гражданского общества в демократических процедурах, а с другой - бюрократический аппарат не всегда в достаточной мере открыт для подобного взаимодействия. Соответственно, в период кризисов выборы нужно преподносить как редкую возможность для граждан собственными силами ускорить наступление «лучших времен». При этом содействие государству могли бы оказать профсоюзы и иные общественные объединения, способные довести информацию о важности участия в голосовании до трудовых коллективов. Очевидно, что в условиях кризисов, помимо электоральных процедур, в дополнительном внимании нуждаются и иные институты, обеспечивающие учет общественных интересов в процессе принятия политико-управленческих решений. Государство может решить эту проблему посредством налаживания каналов так называемого социального лоббизма [Фельдман 2014].

Серьезным подспорьем для электоральной системы в период пандемии могут стать современные достижения технического прогресса, особенно в части цифровизации процедур политического участия граждан. К сожалению, зачастую антикризисные меры не получают должного освещения в информационном пространстве, что обусловлено их потенциальной спорностью в глазах общественности, не желающей идти на серьезные жертвы для стабилизации ситуации в стране. За последнее десятилетие подобный подход несколько утратил свою актуальность, ведь в информационную эру молчание может быть расценено гражданами как признак бездействия властей. Современное государство должно брать на себя инициативу в публичном информационном пространстве и постоянно генерировать общественно значимые послания (особенно в период глобальных и национальных кризисов). Активное использование социальных сетей, сайтов и иных электронных ресурсов в мобилизационных целях 
может не только минимизировать временный спад электоральной активности, но даже и повысить ее уровень (при необходимости).

Ответом на угрозы, связанные с негативной эпидемиологической ситуацией, стало электронное голосование, постепенно внедряемое в России. Так, по вопросу внесения поправок в Конституцию РФ электронным образом проголосовали более 1 млн жителей Москвы и Нижегородской обл. В Единый день голосования 2020 г. подобной цифровой формой волеизъявления охотно воспользовались граждане сразу нескольких регионов страны. К выборам в Государственную думу РФ 2021 г. ЦИК обещает запустить процедуру электронного голосования во всех субъектах РФ. В условиях пандемии COVID-19 это решение выглядит обоснованным, однако для его полноценной реализации необходима модернизация технической инфраструктуры и, самое главное, выработка новых форм наблюдения за ходом онлайн-выборов. В период пандемии задача обеспечения легитимности, честности и прозрачности электоральных процедур не теряет своей актуальности.

Подводя итоги, стоит еще раз указать на особую уязвимость избирательной системы от последствий глобальных кризисов. Для преодоления современных вызовов государство и общество должны взаимодействовать на качественно новом уровне, активно внедряя инновационные формы политического участия.

\section{Список литературы}

Ежов Д.А. 2020. К оценке рисков реализации национальных проектов в условиях пандемии COVID-19. - Власть. T. 28. № 4. С. 23-25.

Фельдман П.Я. 2014. Лоббизм в системе социальных и политических институтов современной России. - Международные отношения. № 3. С. 392-397.

Фельдман П.Я. 2015. Международный лоббизм в условиях глобальной дестабилизации. - Междуународные отношения. № 3. С. 336-340.

\section{IMPROVING ELECTORAL PRACTICES IN TIMES OF GLOBAL CRISES}

\footnotetext{
Abstract. The article assesses the risks for the effective functioning of the electoral system that may arise in the context of global crises. The author concludes that a decline in electoral activity may be a consequence of large-scale crisis phenomena (for example, the COVID-19 pandemic). In these conditions, modern information and communication tools and political technologies that can ensure the mobilization of voters are in particular demand. Accordingly, in the near future, remote forms of political participation have all chances to become a real alternative to traditional practices. Keywords: global crisis, civil society, elections, electoral system, mobilization, electoral activity
} 